\title{
Sistem Pendukung Keputusan Pemilihan Sales Terbaik Menggunakan Metode Rank Order Centroid (ROC) dan Additive Ratio Assessment (ARAS) Berbasis Web
}

\author{
Nindian Puspa Dewi ${ }^{1}$, Ubaidi ${ }^{2}$, Elsi Maharani ${ }^{3}$ \\ ${ }^{1,2,3}$ Program Studi Informatika Fakultas Teknik Universitas Madura \\ 1,2,3 Jl. Raya Panglegur KM.3.5 Pamekasan Madura \\ e-mail: ${ }^{1}$ nindianpd@unira.ac.id, ${ }^{2}$ ubed@unira.ac.id, ${ }^{3}$ elllsy.maharani02@gmail.com
}

\begin{abstract}
Abstrak
Setiap tahun, CV. Anugerah Wangi melakukan pemilihan sales terbaik untuk memotivasi para sales dalam memberikan pelayanan dan peningkatan penjualan sepeda motor. Proses pemilihan sales terbaik masih dilakukan secara manual dengan mengumpulkan data seluruh sales dalam 1 tahun. Pekerjaan ini tentu tidak efektif dan efisien. Selain itu, perhitungan yang dilakukan juga menjadi sulit karena mencakup banyak kriteria penilaian. Karena itulah perlu dibuat suatu sistem pendukung keputusan dalam pemilihan sales terbaik pada CV. Anugerah Wangi yang dapat memudahkan pimpinan untuk melakukan proses perhitungan. Sistem Pendukung Keputusan Pemilihan Sales Terbaik dibuat dengan menggunakan metode Rank Order Centroid (ROC) dan Additive Ratio Assessment (ARAS). Penggabungan metode ROC dan ARAS dapat mengoptimalkan terhadap pembobotan dalam setiap kriteria yang digunakan. Adapun kriteria yang digunakan dalam pemilihan sales terbaik yaitu, jumlah penjualan (C1), penilaian pelayanan (C2), jumlah penjualan (C3), masa bekerja (C4) dan kedisiplinan (C5). Dari penelitian ini, dilakukan uji coba terhadap 23 data sales yang kemudian dilakukan perhitungan sehingga mendapatkan hasil rangking teratas yang menjadi sales terbaik yaitu Faizur Rohman dengan nilai 0,916.
\end{abstract}

Kata kunci: Sales Terbaik, SPK, Sistem Pendukung Keputusan, ROC, ARAS

\begin{abstract}
Every year, CV. Anugerah Wangi selects the best sales to motivate sales in providing services and increasing motorcycle sales. The process of selecting the best sales is still done manually by collecting data on all sales in 1 year. This work is certainly not effective and efficient. In addition, the calculations made also become difficult because it includes many assessment criteria. That why it is necessary to make a decision support system in selecting the best sales for CV. Anugerah Wangi. So, it can make it easier for leaders to carry out the calculation process. The Best Sales Selection Decision Support System was made using the Rank Order Centroid (ROC) and Additive Ratio Assessment (ARAS) methods. The combination of ROC and ARAS methods can optimize the weighting in each of the criteria used. The criteria used in the selection of the best sales are the number of sales (C1), service assessment $(C 2)$, number of sales (C3), years of service (C4), and discipline (C5). From this study, a trial was carried out on 23 sales data which was then calculated so that the top-ranking results were the best sales, namely Faizur Rohman with a value of 0.916.
\end{abstract}

Keywords: Best Sales, DSS, Decision Support System, ROC, ARAS

\section{Pendahuluan}

Semakin pentingnya peranan teknologi dalam operasional perusahaan menjadikan tolak ukur semakin kompetitif sebuah perusahaan. Dengan teknologi pengumpulan dan pengolahan menjadi lebih mudah dan cepat. Salah satunya untuk membantu pimpinan perusahaan dalam mengambil keputusan. Dengan teknologi pengambilan keputusan menjadi lebih cepat, mudah dan data yang dibutuhkan juga dapat diperoleh dengan cepat. CV. Anugerah Wangi merupakan sebuah perusahaan di Pamekasan yang bergerak dibidang penjualan kendaraan sepeda motor Honda. Salah satu faktor yang berperan penting di CV. Anugerah Wangi adalah sales. Seorang 
sales yang menunjukkan kualitasnya tentu akan memiliki kinerja dan juga prestasi yang baik bagi perusahaan. Hasil kerja sales diwujudkan dalam bentuk pelayanan dan pencapaian target tertentu dalam penjualan. Karena itulah perlu adanya pemilihan sales terbaik untuk memberikan apresiasi kepada sales dengan penilaian kinerja yang paling baik. Dengan begitu dapat memotivasi sales untuk selalu memberikan yang terbaik bagi perusahaan. Untuk menentukan sales terbaik, Pimpinan CV. Anugerah Wangi melakukan rekap data penjualan, kehadiran, masa kerja dan lainnya secara manual. Tidak ada sistem yang membantu proses ini, karena selama ini sistem yang berjalan di CV. Anugerah Wangi hanya berupa transaksi penjualan dan rekapitulasi penjualan setiap bulannya. Oleh sebab itu, perlu adanya sistem pendukung keputusan untuk membantu pimpinan dalam proses pemilihan sales terbaik. Penelitian tentang sistem pendukung keputusan telah banyak dilakukan seperti penelitian tentang peramalan [1][2] dan penelitian yang berhubungan dengan penentuan nilai terbaik seperti yang dilakukan oleh Mega Fidia Penta, Fernando dan Sulaeman dalam judul Sistem Pendukung Keputusan untuk Pemilihan Karyawan Terbaik dengan metode SAW [3], penelitian yang dilakukan oleh Rusydi Umar, Abdul Fadlil dan Yuminah yaitu menerapkan Metode AHP dalam Penilaian Kompetensi Soft Skill Karyawan [4], selanjutnya penelitan yang dilakukan oleh Supriyadi, Andysah dan Alfiandi yaitu tentang Pemilihan Pegawai Honorer dengan menggunakan Metode MFEP [5], penelitian yang dilakukan oleh Asnita Susilawati Nadeak tentang Pemilihan Guru Terbaik dengan menerapkan Metode Aras [6]

Penelitian selanjutnya dilakukan oleh Wira Apriani dalam Pemilihan Pimpinan Dengan Metode MAUT [7], penelitian yang dilakukan oleh Samuel Manarung yaitu tentang implementasi metode MOORA dalam Pemilihan Guru Dan Pegawai Terbaik [8], penelitian yang dilakukan oleh Lia Ciky dan Nelly Astuti yaitu metode ARAS digunakan untuk Penentuan Team Leader Shift yang Terbaik [9], penelitian yang dilakukan oleh Andri Yunaldi dalam Menyeleksi Bantuan Pada Siswa Miskin dengan Mengkombinasikan Metode SAW dan ROC [10], penelitian yang dilakukan oleh Ronal Watrianthos, dkk, dengan judul Penerapan Metode Promethee dalam Pemeringkat Siswa [11], dan penelitian yang dilakukan oleh Muhamad Muslihudin dan Dewi Rahayu dalam Penentu Siswa Berprestasi Dengan Metode WP [12].

Sistem Pendukung Keputusan Pemilihan Sales Terbaik ini menggunakan Metode Additive Ratio Assessment (ARAS) dengan kriteria yang ditetapkan yaitu dari jumlah penjualan selama setahun, penilaian pelayanan dari pelanggan, jumlah pelanggaran, masa bekerja, dan kedisiplinan. Metode ARAS merupakan metode yang sederhana dan mudah dalam menghasilkan sebuah keputusan dan proses perangkingan untuk mendapatkan hasil yang lebih tepat dan akurat dalam melakukan perangkingan yaitu dilakukan dengan cara membandingkan dengan alternatif lainnya [13][14][15]. Untuk menentukan sales terbaik perlu adanya penentuan kriteria yang paling penting dari kriteria yang satu dengan yang lainnya. Namun, dalam pemroresan perangkingan dengan metode ARAS, bobot kriteria masih dihasilkan dengan cara pemberian nilai bobot langsung terhadap kriteria. Tentunya hal itu dapat memberikan suatu kelemahan besar dalam proses perangkingan dengan meggunakan metode ARAS. Oleh karena itu, Sistem Pendukung Keputusan ini juga menerapkan Metode Rank Order Centroid (ROC) untuk penentuan bobot kriteria. Dengan ROC ada stabilitas jarak antar bobot kriteria. Penelitian [16][17][18] juga menunjukkan bahwa metode Rank Order Centroid (ROC) dapat membuat pembobotan terhadap kriteria akan menjadi lebih baik. Oleh karena itu, pada penelitian ini juga menerapkan metode Rank Order Centroid (ROC) karena metode ROC merupakan metode yang sederhana dan dapat menghasilkan nilai bobot terhadap kriteria-kriteria yang digunakan dalam penelitian. Dari uraian yang telah dijabarkan, maka penelitian ini dilakukan dengan menggabungkan metode Rank Order Centroid (ROC) dan Additive Ratio Assessment (ARAS) dalam pembuatan Sistem Pendukung Keputusan Pemilihan Sales Terbaik.

\section{Metode Penelitian}

Penelitian tentang sistem pendukung keputusan pemilihan sales terbaik ini terdapat langkahlangkah yang penting untuk dilakukan yaitu pengumpulan data yang menjadi pendukung dari 
masing-masing kriteria, pembobotan kriteria dengan metode ROC, membuat matriks pengambilan keputusan, penormalisasian matriks keputusan untuk semua kriteria, menentukan bobot matriks yang telah dilakukan normalisasi, menghitung nilai dari fungsi optimalisasi, dan menghitung tingkatan peringkat tertinggi alternatif. Secara umum, langkah-langkah dari metode ini dapat dilihat pada Gambar 1 dibawah ini.

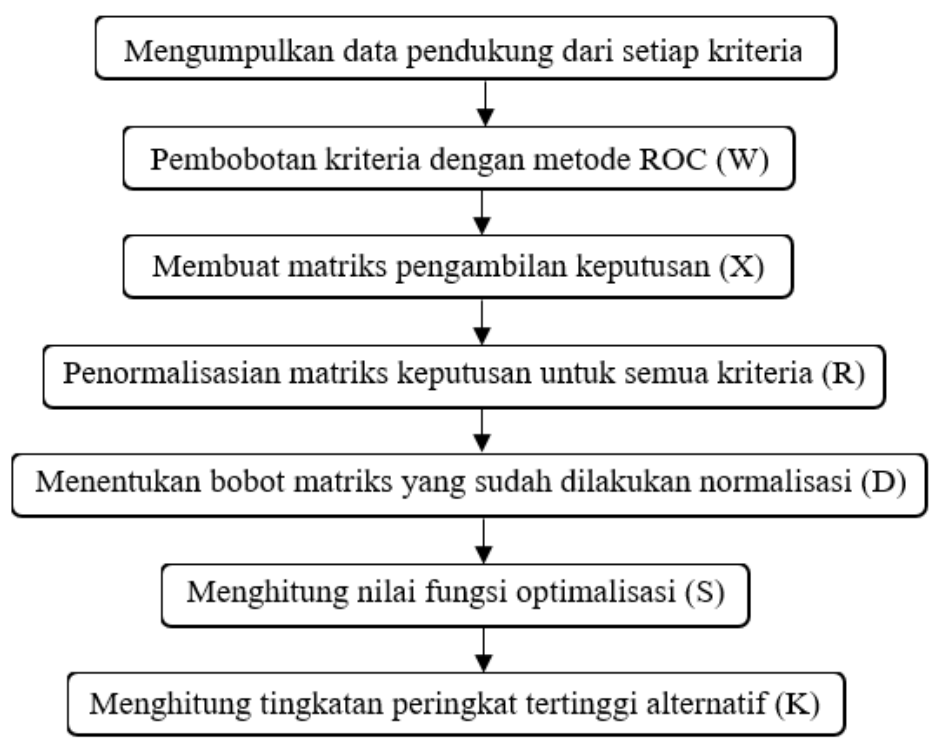

Gambar 1. Tahapan metode ROC dan ARAS

Langkah pertama dalam melakukan perhitungan penentuan sales terbaik dengan menggunakan metode Rank Order Centroid (ROC) dan Additive Ratio Assessment (ARAS) adalah mengumpulkan data pendukung dari setiap kriteria. Setelah data terkumpul, selanjutnya yaitu melakukan pembobotan kriteria dengan menggunakan metode ROC [16]. Lalu untuk perhitungan selanjutnya menggunakan metode ARAS dengan membuat matriks pengambilan keputusan. Setelah itu, melakukan penormalisasian matriks keputusan untuk semua kriteria, menentukan bobot matriks yang telah dilakukan normalisasi, menghitung nilai dari fungsi optimalisasi. Selanjutnya dapat dilakukan dengan menghitung tingkatan peringkat tertinggi alternatif untuk mendapatkan nilai sales terbaik[17][18].

\subsection{Pengumpulan Data}

Objek penelitian ini adalah data sales CV. Anugerah Wangi. Karena itulah, perlu dilakukan pengumpulan data sales yang dilakukan dengan melakukan observasi ke perusahaan CV. Anugerah Wangi Pamekasan. Adapun data yang dikumpulkan meliputi masa bekerja sales, data sepeda motor, data transaksi penjualan unit sepeda motor yang telah terjual oleh sales selama satu tahun, penilaian pelayanan sales dari pelanggan, data jumlah pelanggaran sales, dan data absensi sales. Penelitian ini menggunakan data tahun 2020 untuk dilakukan perhitungan dalam penentuan sales terbaik di CV. Anugerah Wangi.

\subsection{Pembobotan Kriteria dengan Metode Rank Order Centroid (ROC)}

Proses kerja dari metode ROC dalam menghasilkan nilai bobot cukup mudah yaitu dimana kriteria yang pertama merupakan kriteria lebih penting dibandingkan dengan kriteria yang kedua, sedangkan untuk kriteria yang kedua merupakan kriteria lebih penting dibandingkan kriteria yang ketiga, dan begitupun selanjutnya terhadap beberapa kriteria yang digunakan yaitu kriteria keempat dan kriteria kelima. Jika,

$$
\begin{gathered}
C 1 \geq C 2 \geq C 3 \geq \cdots \geq C n \\
\text { Maka, } \\
W 1 \geq W 2 \geq W 3 \geq \cdots \geq W n
\end{gathered}
$$

Secara umum pembobotan ROC dengan menggunakan persamaan (3). 


$$
W k=\frac{1}{k} \sum_{i=k}^{k}\left(\frac{1}{i}\right)
$$

\subsection{Perangkingan dengan Metode Additive Ratio Assessment (ARAS)}

Proses perangkingan menggunakan metode ARAS tentunya ada beberapa langkah yang perlu dilakukan dalam perhitungan sehingga memperoleh hasil perangkingan. Beberapa langkah dari metode ARAS adalah sebagai berikut:

Langkah 1. Membuat matriks pengambilan keputusan (Pembentukan Decission Making Matriks)

Membuat matriks pengambilan keputusan (X) dengan menggunakan persamaan (4).

dimana,

$$
\left[\begin{array}{cccc}
X 0 l & X 0 l & \ldots & X 0 n \\
X i l & X i j & \ldots & X i n \\
\vdots & \vdots & \ddots & \vdots \\
X n l & X m j & \ldots & X m n
\end{array}\right]
$$

$\mathrm{m}=$ Jumlah dari Alternatif

$\mathrm{n} \quad=$ Jumlah dari Kriteria

$\mathrm{Xij}=$ Nilai performa dari alternatif I terhadap kriteria $\mathrm{j}$

$\mathrm{X} 0 \mathrm{j}=$ Nilai optimum dari kriteria $\mathrm{j}$

Jika nilai optimal kriteria $\mathrm{j}(\mathrm{X} 0 \mathrm{j})$ tidak diketahui, maka menggunakan persamaan (5) dan (6).

$$
\begin{aligned}
& X 0 j=\frac{\max }{1} \cdot X i j \text { if }=\frac{\max }{1} \cdot X i j \quad, \text { is Benefit } \\
& X 0 j=\frac{\min }{1} \cdot X i j \text { if }=\frac{\min }{1} \cdot X i j \quad, \text { is Cost }
\end{aligned}
$$

Langkah 2. Penormalisasian matriks keputusan untuk semua kriteria

Jika kriteria termasuk Beneficial (Benefit) maka perlu dilakukan normalisasi dengan menggunakan persamaan (7).

$$
X i j *=\frac{X i j}{\sum_{i=0}^{m} X i j}
$$

dimana,

$\mathrm{Xij}^{*}=$ Nilai Normalisasi

Namun, jika kriteria termasuk Non-Beneficial (Cost) maka perlu dilakukan normalisasi menggunakan persamaan (8) dan (9).

Langkah-1:

$$
X i j *=\frac{1}{X i j}
$$

Dan langkah-2:

$$
R=\frac{X i j}{\sum_{i=0}^{m} X i j}
$$

Langkah 3. Menentukan bobot matriks yang sudah dilakukan normalisasi

Dalam proses penentuan bobot matriks yang telah dilakukan normalisasi (D) dengan menggunakan persamaan (10).

$$
D=[D i j] m X n=R i j \cdot W j
$$

dimana,

$\mathrm{Wj}=$ Bobot dari Kriteria

Langkah 4. Menghitung nilai dari fungsi optimalisasi (Si) 
Menentukan nilai fungsi optimalisasi (Si) dengan menggunakan persamaan (11).

$$
\mathrm{Si}=\sum_{j}^{n}=1 \mathrm{Dij}:(i=1,2, \ldots m: j=1,2, \ldots, n)
$$

dimana,

$\mathrm{Si}=$ Nilai dari fungsi optimalisasi alternatif $\mathrm{i}$

Nilai terbaik adalah nilai yang terbesar, dan sebaliknya nilai terburuk adalah nilai yang terendah. Memperhitungkan proses hubungan proposional dengan nilai bobot kriteria sangat berpengaruh pada hasil akhir.

\section{Langkah 5. Menghitung tingkatan peringkat tertinggi dari alternatif}

Dalam mengetahui tingkatan peringkat tertinggi dari alternatif dengan menggunakan persamaan (12).

$$
K=\frac{S i}{S 0}
$$

\section{Hasil dan Pembahasan}

Data yang dijadikan sebagai data pendukung dalam penelitian ini adalah data sales, data sepeda motor, data transaksi penjualan sales, data penilaian pelayanan dari pelanggan, data jumlah pelanggaran, dan data absensi sales di CV. Anugerah Wangi Pamekasan pada Tahun 2020. Total jumlah data sales adalah 23 orang sales, total jumlah data transaksi penjualan sales adalah 1.563 unit selama tahun 2020.

Pada bagian ini kriteria yang digunakan meliputi Jumlah Penjualan, Penilaian Pelayanan, Jumlah Pelanggaran, Masa Bekerja, dan Kedisiplinan. Dari 5 kriteria tersebut, perlu dilakukan pemberian bobot dengan metode Rank Order Centroid (ROC), berikut perhitungan dengan menerapkan persamaan (3).

$$
\begin{aligned}
& W k=\frac{1+\frac{1}{2}+\frac{1}{3}+\frac{1}{4}+\frac{1}{5}}{5}=0,457 \\
& W k=\frac{0+\frac{1}{2}+\frac{1}{3}+\frac{1}{4}+\frac{1}{5}}{5}=0,257 \\
& W k=\frac{0+0+\frac{1}{3}+\frac{1}{4}+\frac{1}{5}}{5}=0,156 \\
& W k=\frac{0+0+0+\frac{1}{4}+\frac{1}{5}}{5}=0,090 \\
& W k=\frac{0+0+0+0+\frac{1}{5}}{5}=0,040
\end{aligned}
$$

Dalam penelitian ini ada 5 kriteria yang digunakan dalam penentuan sales terbaik, yaitu Jumlah Penjualan, Penilaian Pelayanan, Jumlah Pelanggaran, Masa Bekerja dan Kedisiplinan. Dimana kriteria Jumlah Penjualan lebih penting daripada Penilaian Pelayanan, Penilaian Pelayanan lebih penting dari Jumlah Pelanggaran, Jumlah Pelanggaran lebih penting dari Masa Bekerja, dan Masa Bekerja lebih penting daripada Kedisiplinan. Data kriteria dan urutan kepentingannya ditunjukkan pada Tabel 1. 
Tabel 1. Tabel Kriteria Sales Terbaik

\begin{tabular}{ccll}
\hline Kriteria & Keterangan & Jenis & Bobot \\
\hline C1 & Jumlah Penjualan & Benefit & 0,457 \\
C2 & Penilaian Pelayanan & Benefit & 0,257 \\
C3 & Jumlah Pelanggaran & Cost & 0,156 \\
C4 & Masa Bekerja & Benefit & 0,090 \\
C5 & Kedisiplinan & Benefit & 0,040 \\
\hline
\end{tabular}

Karena yang akan dicari adalah sales terbaik, maka data sales dijadikan sebagai alternatif yang akan di uji. Berikut nama dari sales yang menjadi alterinatif ditunjukkan pada Tabel 2.

Tabel 2. Data Sales sebagai Alternatif

\begin{tabular}{cc}
\hline Alternatif & Keterangan \\
\hline A1 & Miftahol Hairi \\
A2 & Janny Kumalasari \\
A3 & Benni Lurniawan \\
A4 & Siti Nuraini \\
A5 & Moh Imam Kasiyanto \\
A6 & Abd. Mukit \\
A7 & Mohammad Qodir Muhyei \\
A8 & Yogha Alief Suhermanto \\
A9 & Moh. Sudar Firmanto \\
A10 & Muhammad Rudi \\
A11 & Mohammad Anwar \\
A12 & Ulfa Safitri \\
A13 & Ary Kuswanto \\
A14 & Faizur Rohman \\
A15 & Syamsul Arifin \\
A16 & Retno Palupi \\
A17 & Moh. Rifhanul Faiz Mz \\
A18 & Dai Yanto \\
A19 & Samsul Arifin \\
A20 & Amiruddin \\
A21 & Ainak Sandys Alfidhdhah \\
A22 & Kusairi \\
A23 & Setiap Krite Tab 3-7 \\
\hline
\end{tabular}

Selanjutnya memberi Bobot Nilai untuk Setiap Kriteria. Tabel 3-7 menunjukkan Nilai dari setiap kriteria dibobotkan.

Tabel 3. Pembobotan Nilai Kriteria Jumlah Penjualan

\begin{tabular}{cc}
\hline Keterangan & Nilai Bobot \\
\hline $1-25$ unit & 1 \\
$26-50$ unit & 2 \\
$51-75$ unit & 3 \\
$76-100$ unit & 4 \\
$>100$ unit & 5 \\
\hline
\end{tabular}


Tabel 4. Pembobotan Nilai Kriteria Penilaian Pelayanan

\begin{tabular}{cc}
\hline Keterangan & Nilai Bobot \\
\hline Tidak Baik & 1 \\
Kurang Baik & 2 \\
Cukup Baik & 3 \\
Baik & 4 \\
Sangat Baik & 5
\end{tabular}

Tabel 5. Pembobotan Nilai Kriteria Jumlah Pelanggaran

\begin{tabular}{cc}
\hline Keterangan & Nilai Bobot \\
\hline$>3$ kali & 1 \\
3 kali & 2 \\
2 kali & 3 \\
1 kali & 4 \\
Tidak Pernah & 5
\end{tabular}

Tabel 6. Pembobotan Nilai Kriteria Masa Bekerja

\begin{tabular}{cc}
\hline Keterangan & Nilai Bobot \\
\hline$<1$ tahun $-<2$ tahun & 1 \\
2 tahun $-<3$ tahun & 2 \\
3 tahun $-<4$ tahun & 3 \\
4 tahun $-<5$ tahun & 4 \\
$>=5$ tahun & 5 \\
\hline
\end{tabular}

Tabel 7. Pembobotan Nilai Kriteria Kedisiplinan

\begin{tabular}{cc}
\hline Keterangan & Nilai Bobot \\
\hline Tidak Disiplin & 1 \\
Kurang Disiplin & 2 \\
Cukup Disiplin & 3 \\
Disiplin & 4 \\
Sangat Disiplin & 5
\end{tabular}

Tabel 8 menunjukkan matrik dari alternatif (sales) dengan data sesuai dengan kriteria yang telah ditentukan sebelumnya.

Tabel 8. Data Pengujian Calon Sales Terbaik

\begin{tabular}{cccccc}
\hline Alternatif & $\begin{array}{c}\text { Jumlah } \\
\text { Penjualan }\end{array}$ & $\begin{array}{c}\text { Penilaian } \\
\text { Pelayanan }\end{array}$ & $\begin{array}{c}\text { Jumlah } \\
\text { Pelanggaran }\end{array}$ & $\begin{array}{c}\text { Masa } \\
\text { Bekerja }\end{array}$ & Kedisiplinan \\
\hline A1 & 64 Unit & Baik & Tidak Pernah & 4 tahun & Disiplin \\
A2 & 161 Unit & Baik & Tidak Pernah & 4 tahun & Disiplin \\
A3 & 125 Unit & Baik & 1 Kali & 4 tahun & Cukup Disiplin \\
A4 & 30 Unit & Baik & 1 Kali & 4 tahun & Cukup Disiplin \\
A5 & 32 Unit & Baik & Tidak Pernah & 4 tahun & Disiplin \\
A6 & 28 Unit & Baik & Tidak Pernah & 4 tahun & Cukup Disiplin \\
A7 & 58 Unit & Baik & 2 Kali & 4 tahun & Disiplin \\
A8 & 48 Unit & Baik & Tidak Pernah & 4 tahun & Cukup Disiplin \\
A9 & 67 Unit & Baik & 1 Kali & 4 tahun & Disiplin \\
A10 & 42 Unit & Baik & Tidak Pernah & 3 tahun & Cukup Disiplin \\
A11 & 62 Unit & Baik & Tidak Pernah & 3 tahun & Cukup Disiplin \\
A12 & 59 Unit & Baik & Tidak Pernah & 3 tahun & Disiplin \\
A13 & 54 Unit & Baik & 1 Kali & 3 tahun & Cukup Disiplin \\
A14 & 49 Unit & Baik & 1 Kali & 3 tahun & Disiplin \\
A15 & 148 Unit & Baik & 3 Kali & 2 tahun & Disiplin \\
A16 & 84 Unit & Baik & Tidak Pernah & 2 tahun & Cukup Disiplin \\
A17 & 136 Unit & Baik & Tidak Pernah & 2 tahun & Disiplin \\
\hline
\end{tabular}




\begin{tabular}{cccccc} 
Alternatif & $\begin{array}{c}\text { Jumlah } \\
\text { Penjualan }\end{array}$ & $\begin{array}{c}\text { Penilaian } \\
\text { Pelayanan }\end{array}$ & $\begin{array}{c}\text { Jumlah } \\
\text { Pelanggaran } \\
\text { Tidak Pernah }\end{array}$ & $\begin{array}{c}\text { Masa } \\
\text { Bekerja }\end{array}$ & Kedisiplinan \\
A18 & 32 Unit & Baik & Cukup Disiplin \\
A19 & 47 Unit & Baik & 1 Kali & 2 tahun & Cukup Disiplin \\
A20 & 79 Unit & Baik & Tidak Pernah & 2 tahun & Cukup Disiplin \\
A21 & 37 Unit & Baik & Tidak Pernah & 2 tahun & Cukup Disiplin \\
A22 & 119 Unit & Baik & 1 Kali & 2 tahun & Disiplin \\
A23 & 2 Unit & Sangat Baik & 2 Kali & 1 tahun & Cukup Disiplin \\
\hline
\end{tabular}

Setelah data terkumpul, langkah berikutnya adalah melakukan rating kecocokan alternatif pada setiap kriteria yang telah dibuat.

Tabel 9. Rating Kecocokan Alternatif Pada Setiap Kriteria

\begin{tabular}{cccccc}
\hline Alternatif & C1 & C2 & C3 & C4 & C5 \\
\hline A1 & 3 & 4 & 5 & 4 & 4 \\
A2 & 5 & 4 & 5 & 4 & 4 \\
A3 & 5 & 4 & 4 & 4 & 3 \\
$\ldots$ & $\ldots$ & $\ldots$ & $\ldots$ & $\ldots$ & $\ldots$ \\
A22 & 5 & 4 & 4 & 2 & 4 \\
A23 & 1 & 5 & 3 & 1 & 3 \\
\hline
\end{tabular}

Selanjutnya melakukan perhitungan perangkingan menggunakan metode Additive Ratio Assessment (ARAS). Untuk menyelesaikan masalah diatas menggunakan metode Additive Ratio Assessment (ARAS) yang pertama yaitu Pembentukan Decision Making Matriks dari data rating kecocokan.

Tabel 10. Tabel Matriks Pengambilan Keputusan

\begin{tabular}{cccccc}
\hline Alternatif & C1 & C2 & C3 & C4 & C5 \\
\hline A0 & 5 & 5 & 2 & 4 & 4 \\
A1 & 3 & 4 & 5 & 4 & 4 \\
A2 & 5 & 4 & 5 & 4 & 4 \\
A3 & 5 & 4 & 4 & 4 & 3 \\
$\ldots$ & $\ldots$ & $\ldots$ & $\ldots$ & $\ldots$ & $\ldots$ \\
A22 & 5 & 4 & 4 & 2 & 4 \\
A23 & 1 & 5 & 3 & 1 & 3 \\
Criteria Type & Max & Max & Min & Max & Max
\end{tabular}

Setelah melakukan perhitungan perangkingan, Selanjutnya merumuskan matriks keputusan dengan menggunakan persamaan (4).

$$
\mathrm{Xij}=\left(\begin{array}{ccccc}
5 & 5 & 2 & 4 & 4 \\
3 & 4 & 5 & 4 & 4 \\
5 & 4 & 5 & 4 & 4 \\
5 & 4 & 4 & 4 & 3 \\
\ldots & \ldots & \ldots & \ldots & \ldots \\
5 & 4 & 4 & 2 & 4 \\
1 & 5 & 3 & 1 & 3
\end{array}\right)
$$

Matriks diatas dijumlahkan kebawah sehingga mendapatkan hasil [75, 98, 103, 72, 83]. Langkah selanjutnya normalisasi matriks keputusan untuk semua kriteria.

Berikut adalah normalisasi matriks keputusan $\mathrm{C} 1$ (Kriteria Benefit) dengan menggunakan persamaan (7).

$$
\begin{aligned}
& R_{01}=\frac{5}{75}=0,067 \\
& R_{11}=\frac{3}{75}=0,04
\end{aligned}
$$


Berikut adalah normalisasi matriks keputusan C3 (Kriteria Cost) yang terdiri dari 2 langkah, langkah 1 dengan menggunakan persamaan (8).

$$
\begin{aligned}
& X_{03}=\frac{1}{2}=0,5 \\
& X_{13}=\frac{1}{5}=0,2
\end{aligned}
$$

Langkah 2 dengan menggunakan persamaan (9).

$$
\begin{aligned}
& R_{03}=\frac{0,5}{6,017}=0,083 \\
& X_{13}=\frac{0,2}{6,017}=0,033
\end{aligned}
$$

Setelah melakukan perhitungan seperti diatas maka diperoleh hasil matriks pengambilan keputusan yang telah dilakukan normalisasi, hasilnya seperti tabel berikut ini:

Tabel 11. Hasil Normalisasi

\begin{tabular}{cccccc}
\hline Alternatif & C1 & C2 & C3 & C4 & C5 \\
\hline A0 & 0,067 & 0,051 & 0,083 & 0,056 & 0,048 \\
A1 & 0,04 & 0,041 & 0,033 & 0,056 & 0,048 \\
A2 & 0,067 & 0,041 & 0,033 & 0,056 & 0,048 \\
A3 & 0,067 & 0,041 & 0,042 & 0,056 & 0,036 \\
$\ldots$ & $\ldots$ & $\ldots$ & $\ldots$ & $\ldots$ & $\ldots$ \\
A22 & 0,067 & 0,041 & 0,042 & 0,028 & 0,048 \\
A23 & 0,013 & 0,051 & 0,055 & 0,014 & 0,036 \\
\hline
\end{tabular}

Kemudian langkah selanjutnya menentukan bobot matriks yang telah dinormalisasikan yaitu dengan cara melakukan perkalian matriks hasil normalisasi dengan bobot kriteria, menggunakan persamaan (10).

$$
\begin{gathered}
C 1: D_{01}=X_{01} * W_{1}=0,067 * 0,457=0,03 \\
D_{11}=X_{11} * W_{1}=0,04 * 0,457=0,018 \\
D_{21}=X_{21} * W_{1}=0,067 * 0,457=0,03 \\
D_{31}=X_{31} * W_{1}=0,067 * 0,457=0,03 \\
\ldots \\
D_{221}=X_{221} * W_{1}=0,067 * 0,457=0,03 \\
D_{231}=X_{231} * W_{1}=0,013 * 0,457=0,006
\end{gathered}
$$

Setelah perhitungan seperti diatas telah dilakukan maka diperoleh hasil matriks seperti tabel dibawah ini.

Tabel 12. Hasil Normalisasi Terbobot

\begin{tabular}{cccccc}
\hline Alternatif & C1 & C2 & C3 & C4 & C5 \\
\hline A0 & 0,03 & 0,013 & 0,013 & 0,005 & 0,002 \\
A1 & 0,018 & 0,01 & 0,005 & 0,005 & 0,002 \\
A2 & 0,03 & 0,01 & 0,005 & 0,005 & 0,002 \\
A3 & 0,03 & 0,01 & 0,006 & 0,005 & 0,001 \\
$\ldots$ & $\ldots$ & $\ldots$ & $\ldots$ & $\ldots$ & $\ldots$ \\
A22 & 0,03 & 0,01 & 0,006 & 0,003 & 0,002 \\
A23 & 0,006 & 0,013 & 0,009 & 0,001 & 0,001 \\
\hline
\end{tabular}

Setelah hasil normalisasi terbobot sudah didapatkan, langkah selanjutnya yaitu menentukan nilai dari fungsi optimalisasi, dengan menjumlahkan nilai kriteria pada setiap alternatif dari hasil normalisasi terbobot yang telah diperoleh, dapat dilihat pada persamaan (11). 


$$
\begin{aligned}
& S_{0}=0,03+0,013+0,013+0,005+0,002=0,063 \\
& S_{1}=0,018+0,01+0,005+0,005+0,002=0,041 \\
& S_{2}=0,03+0,01+0,005+0,005+0,002=0,053 \\
& S_{3}=0,03+0,01+0,006+0,005+0,001=0,054 \\
& \ldots \\
& S_{22}=0,03+0,01+0,006+0,003+0,002=0,052 \\
& S_{23}=0,006+0,013+0,009+0,001+0,001=0,031
\end{aligned}
$$

Langkah selanjutnya, menghitung untuk mengetahui tingkatan peringkat tertinggi dari alternatif, yaitu pembagian nilai alternatif dengan alternatif hasil S0 (A0), dapat diilihat pada persamaan (12).

$$
\begin{aligned}
& K_{0}=\frac{0,063}{0,063}=1 \\
& K_{1}=\frac{0,041}{0,063}=0,644
\end{aligned}
$$

Tabel 13. Alternatif Diurutkan dari Nilai Tertinggi

\begin{tabular}{ccccc}
\hline Alternatif & Nama Sales & Total & Nilai K & Rangking \\
\hline A0 & - & 0,064 & 1 & - \\
A15 & Faizur Rohman & 0,058 & 0,916 & 1 \\
A3 & Jufri Kurniawan & 0,054 & 0,847 & 2 \\
A2 & Yanny Kumalasari & 0,053 & 0,832 & 3 \\
A22 & Ainak Sandys Alfidhdhah & 0,052 & 0,815 & 4 \\
A17 & Retno Palupi & 0,050 & 0,793 & 5 \\
A7 & Abd. Mukit & 0,044 & 0,693 & 6 \\
A20 & Samsul Arifin & 0,043 & 0,685 & 7 \\
A16 & Syamsul Arifin & 0,043 & 0,685 & 8 \\
A9 & Yogha Alief Suhermanto & 0,042 & 0,662 & 9 \\
A1 & Miftahol Hairi & 0,040 & 0,639 & 10 \\
A13 & Ulfa Safitri & 0,040 & 0,634 & 11 \\
A12 & Mohammad Anwar & 0,039 & 0,620 & 12 \\
A11 & Muhammad Rudi & 0,039 & 0,612 & 13 \\
A4 & Benni Lismarta & 0,035 & 0,561 & 14 \\
A14 & Ary Kuswanto & 0,035 & 0,549 & 15 \\
A5 & Siti Nuraini & 0,035 & 0,547 & 16 \\
A8 & Mohammad Qodir Muhyei & 0,034 & 0,539 & 17 \\
A18 & Moh Imam Kasiyanto & 0,034 & 0,539 & 18 \\
A19 & Dai Yanto & 0,033 & 0,522 & 19 \\
A20 & Moh. Sudar Firmanto & 0,033 & 0,519 & 20 \\
A21 & Amiruddin & 0,032 & 0,500 & 21 \\
A22 & Moh. Rifhanul Faiz Mz & 0,032 & 0,500 & 22 \\
A23 & Kusairi & 0,030 & 0,474 & 23 \\
\hline Beri
\end{tabular}

Berdasarkan hasil perhitungan di atas maka dari 23 sales CV. Anugerah Wangi dengan beberapa nilai kriteria dan nilai bobot yang ditentukan dengan metode Rank Order Centroid (ROC) diperoleh nilai tertinggi yaitu A15 dengan nilai 0,916 atas nama sales Faizur Rohman. Pada hasil uji coba, sales A20 dan A16 memiliki nilai akhir yang sama, namun sistem bisa mengurutkan secara otomatis sesuai dengan tingkat kepentingan kriteria. Dibandingkan dengan penelitian sebelumnya [13][14][15], pembobotan dengan menggunakan ROC menggunakan nilai yang lebih proporsional sehingga hasil penilaian ini menjadi lebih objektif. Selain itu, Sistem pendukung keputusan ini memberikan efisiensi waktu berupa kemudahan pada pimpinan 
untuk melihat, mengumpulkan dan melakukan proses perhitungan untuk menentukan sales terbaik. Dengan sistem ini pimpinan hanya cukup mengimport data dari sistem yang lama. Sistem ini juga menyediakan layanan sistem berupa input data pelayanan dari pembeli saat transaksi selesai dilakukan.

\section{Kesimpulan}

Penerapan metode Additive Ratio Assesment (ARAS) dengan menggunakan Rank Order Centroid (ROC) untuk pembobotan kriteria menghasilkan aplikasi pendukung keputusan yang dapat membantu Pimpinan CV.Anugerah Wangi untuk menentukan sales terbaik. Pembobotan dengan menggunakan ROC menggunakan nilai yang lebih proporsional sehingga penilaian ini menjadi lebih objektif. Dengan penerapan sistem pendukung keputusan maka tercapai juga efektivitas dan efisiensi waktu daripada menggunakan perhitungan secara manual.

\section{Daftar Pustaka}

[1] N. P. Dewi, and Indah Listiowarni, "Peramalan Harga Bahan Proyek Menggunakan Metode Least Square (Studi Kasus : CV Rizky Mulya)." Jurnal Teknologi Informatika (J-TIFA), vol. 2, no. 1, pp. 27-33, 2019.

[2] N. P. Dewi, and Indah Listiowarni, "Implementasi Holt-Winters Exponential Smoothing untuk Peramalan Harga Bahan Pangan di Kabupaten Pamekasan" Digital Zone: Jurnal Teknologi Informasi Dan Komunikasi, vol. 11, no. 2, pp. 223-236, 2020, doi: 10.31849/digitalzone.v11i2.4797.

[3] M. F. Penta, F. B. Siahaan, and S. H. Sukamana, "Sistem Pendukung Keputusan Pemilihan Karyawan Terbaik Menggunakan Metode SAW pada PT. Kujang Sakti Anugrah," JSAI (Journal Sci. Appl. Informatics), vol. 2, no. 3, pp. 185-192, 2019, doi: 10.36085/jsai.v2i3.410.

[4] R. Umar, A. Fadlil, and Y. Yuminah, "Sistem Pendukung Keputusan dengan Metode AHP untuk Penilaian Kompetensi Soft Skill Karyawan," Khazanah Inform. J. Ilmu Komput. dan Inform., vol. 4, no. 1, p. 27, 2018, doi: 10.23917/khif.v4i1.5978.

[5] S.- Supiyandi, A. P. U. Siahaan, and A. Alfiandi, "Sistem Pendukung Keputusan Pemilihan Pegawai Honorer Kelurahan Babura dengan Metode MFEP," J. Media Inform. Budidarma, vol. 4, no. 3, p. 567, 2020, doi: 10.30865/mib.v4i3.2107.

[6] A. S. Nadeak, "Penerapan Metode ARAS (Additive Ratio Assessment) Dalam Penilaian Guru Terbaik," Semin. Nas. Teknol. Komput. Sains SAINTEKS 2019, pp. 571-578, 2019.

[7] I. R. Munthe, B. H. Rambe, R. Pane, D. Irmayani, and M. Nasution, "Sistem Pendukung Keputusan Pemilihan Pimpinan Dengan Metode Multi Attribute Utility Theory (MAUT) di PT. Sagami Indonesia," J. Mantik, vol. 3, no. January, pp. 31-38, 2019.

[8] S. Manurung, "Sistem Pendukung Keputusan Pemilihan Guru Dan Pegawai Terbaik Menggunakan Metode Moora," Simetris J. Tek. Mesin, Elektro dan Ilmu Komput., vol. 9, no. 1, pp. 701-706, 2018, doi: 10.24176/simet.v9i1.1967.

[9] N. A. H. Lia Ciky Lumban Gaol, "Sistem pendukung keputusan pemilihan team leader shift terbaik dengan menggunakan metode aras studi kasus pt. Anugrah busana indah Lia," Inf. dan Teknol. Ilm., vol. 13, no. 1, pp. 16-21, 2018.

[10] A. Yunaldi, "Sistem Pendukung Keputusan Seleksi Bantuan Siswa Miskin Menerapkan Kombinasi Metode SAW dan ROC," J. Media Inform. Budidarma, vol. 3, no. 4, p. 376, 2019, doi: 10.30865/mib.v3i4.1511.

[11] R. Watrianthos, K. Kusmanto, E. F. S. Simanjorang, M. Syaifullah, and I. R. Munthe, "Penerapan Metode Promethee Sebagai Sistem Pendukung Keputusan Pemeringkatan Siswa," J. Media Inform. Budidarma, vol. 3, no. 4, p. 381, 2019, doi: 10.30865/mib.v3i4.1546.

[12] M. Muslihudin and D. Rahayu, "Sistem pendukung keputusan siswa berprestasi menggunakan metode weighted product | Muslihudin | Jurnal TAM (Technology 
Acceptance Model)," J. TAM (Technology Accept. Model., vol. 9, no. 2, pp. 114-119, 2018.

[13] A. Sari, N. A. Hasibuan, and I. Saputra, "Sistem Pendukung Keputusan Pemilihan Tinter Kaca Film Terbaik Menggunakan Metode Aras (Studi Kasus: Pt. Degree the Ambassador)," KOMIK (Konferensi Nas. Teknol. Inf. dan Komputer), vol. 3, no. 1, pp. 307-315, 2019, doi: 10.30865/komik.v3i1.1606.

[14] L. Joli Afriany, "Penerapan Metode ARAS Guna Mendukung Keputusan Produk Unggulan Daerah,” Semin. Nas. Teknol. Komput. Sains, vol. 1, no. 1, pp. 441-447, 2019.

[15] F. Pratiwi, F. Tinus Waruwu, D. Putro Utomo, and R. Syahputra, "Penerapan Metode Aras Dalam Pemilihan Asisten Perkebunan Terbaik Pada PTPN V," Semin. Nas. Teknol. Komput. Sains SAINTEKS 2019, pp. 651-662, 2019.

[16] R. Kharisman Ndruru, "Penerapan Metode Additive Ratio Assessment (ARAS) dan Rank Order Centroid (ROC) Dalam Pemilihan Jaksa Terbaik Pada Kejaksaan Negeri Medan,” Semin. Nas. Teknol. Komput. Sains, pp. 367-372, 2020.

[17] L. Handayani, M. Syahrizal, and K. Tampubolon, "Pemilihan Kepling Teladan Menerapkan Metode Rank Order Centroid (Roc) Dan Metode Additive Ratio Assessment (Aras) Di Kecamatan Medan Area," KOMIK (Konferensi Nas. Teknol. Inf. dan Komputer), vol. 3, no. 1, pp. 532-538, 2019, doi: 10.30865/komik.v3i1.1638.

[18] M. Mesran, J. Afriany, and S. H. Sahir, "Efektifitas Penilaian Kinerja Karyawan Dalam Peningkatan Motivasi Kerja Menerapkan Metode Rank Order Centroid (ROC) dan Additive Ratio Assessment (ARAS)," Pros. Semin. Nas. Ris. Inf. Sci., vol. 1, no. September, p. 813, 2019, doi: 10.30645/senaris.v1i0.88.

\section{(i) (2)}

BY SA Digital Zone: Jurnal Teknologi Informasi dan Komunikasi is licensed under a_Creative Commons Attribution International (CC BY-SA 4.0) 